\title{
From segregation to protagonism. The great lesson of young blind people in Italy \\ Roberta Caldin*
}

\begin{abstract}
Special Pedagogy is a continuous composition of relations, actions and projects. Special Pedagogy should not have the presumption to consider worthy only those questions to which we already know the answer. It should learn to live with questions that do not have ready prepared answers. Its task is to seek answers without being sure of finding them. Special Pedagogy owes much of its knowledge and wealth of experience to the cultural presence of persons with disabilities: in this paper, thanks to the efforts of people with disabilities and their fight for civil rights in Italy, we present the historical and socio-cultural path from segregation (institutionalization) to the inclusion in the society of blind people, with a particular attention paid to the adolescenthood.
\end{abstract}

Keywords: inclusion, disability, rights, project of life, Special Education

\section{The possible impossible}

\section{Special Pedagogy}

"[...] is a continuous composition of relations, actions, projects and viewpoints. And above all, many questions. Which cannot always be answered by what is already known. Special Pedagogy should not have the presumption - which is disastrous for its very existence -, to consider worthy only those questions to which we already know the answer. It should learn to live with questions that do not have ready prepared answers. Its task is to seek answers without being sure of finding them. Its task is to live with open answers, real and authentic answers» (Canevaro, 2013, p. 183).

The conceptual framework of Canevaro's statement seems to respond to a question which today is more appropriate than ever, forcing us to look into the mirror of cultural changes seeking an - also political - passage from the welfarist dimension to that of autonomies and self-determination, the international dimension and the relations with other disciplines.

${ }^{*}$ Full Professor of Special Education, Department of Education Studies, Bologna University. E-mail: roberta.caldin@unibo.it. 
Special Pedagogy owes much of its knowledge and wealth of experience to the cultural presence of persons with disabilities, as this discipline is always considered in research, above all in some particularly complex areas, in which there is still a huge amount of work to be done (multiple disabilities, migration, traumas, employability). It must in fact be said that we have become more competent at looking at some areas of deficit; in others, on the other hand, we must develop further, continuing to investigate, persevering to learn more, progressing our knowledge, avoiding the risk that complicity and ignorance become a maze in which we lose both responsibilities and dignity. To do this, we need competent contexts offering stimulating competence, able to overcome both welfarism and victimism, risks which Canevaro (2013) indicates with extraordinary lucidity, suggesting that welfarism can be overcome by an evolved, participatory project and victimism can be fought by "avoiding support that removes the responsibility of persons with disabilities and strives rather to ensure they can actively organise themselves", these indications have been experienced and implemented by young blind people in Italy who, since the 1960s, have fought many battles. These young people with a disability - a visual deficit - seek innovative stimulation for themselves, their own condition, but also towards the institutions which host them, deemed no longer able to satisfy the needs of a complex society and a personal life project based on selfdetermination and responsibility.

Sight remains the first means/mediator for interacting with reality; the difficulty of "not seeing" - in a society which is predominantly (and increasingly more so) visual - creates various types of problems, in different contexts: reflection is needed on the fact that a society - almost entirely organised by visual aspects - must instead guarantee situations and opportunities, also protecting those who live their everyday lives in non-visual dimensions.

Blindness is an extremely (and paradoxically) visible and limiting deficit, characterised by signs and stigmas (dog, glasses, white stick, etc.) which Goffman (1970) well analysed, and this has made the discussion special and exclusive; the situation is different in relation to low vision, which has a dimension of temporariness, given that, for example, it may be more pronounced at certain times of the day, or may relate to peripheral vision, or central vision, and so on. In this light, the issue of capabilities is very current, and directly linked to that of the true freedom of choice of the individual, in his or her actions; capabilities describe the degrees of freedom of action of a person in transforming their own preferences into realisation, and are therefore the expression of the freedom to implement one's own functioning. In other words, everyone should be put in the condition to be able to activate their own, different, personal possibilities (Ghedin, 2010; Sen, 1999); in this sense, in 
terms of inclusion, educational freedom becomes the freedom of development, growth, participation, emancipation; but also the freedom from physical, mental, social, economic, political constraints which slow down or impede the development of individual potential, as happened in the years before deinstitutionalisation. It should be recalled that the relationship between possible and impossible is presented - in the education field - as a "mobile relationship" which, broadening the possible elements, helps us to become increasingly closer to others, deemed impossible. Canevaro writes: «The impossible is a relative element, and needs to be reformulated in order to understand that what is presented as impossible in a formulation, in a method, can become less impossible, and therefore enter the area of the possible when managed with a different formulation» (Canevaro, 1999, p. 104-105). In this sense, and by investing in education in the institutions, what which was once deemed impossible - the inclusion of blind people in society and in regular school paths - is now a fact in Italy, protected by laws, and current attention now focuses above all - on the continuous improvement of these inclusive processes. Musil uses the term sense of possibility to describe all that contributes to imagining/prefiguring a possibility of change in a given situation, freeing it from deterministic elements: "If the sense of reality exists, and nobody can doubt that its existence is justified, then there must also be something that we call the sense of possibility. Those who have it do not say, for example, here this happened, or this will happen, it must happen; but imagines: here one thing or another could and should happen; and if you tell him that something is as it is, he thinks: well, it could probably also be different. And thus the sense of possibility could also be defined as the ability to think of all that could be and not give greater importance to what it is or isn't" (Musil, 1957, p. 12) ${ }^{1}$.

In almost all countries, integration and inclusion of disabled persons begin precisely with the blind, considering blindness to be a "noble deficit", which neither affects nor hinders the rational processes of language and thought; frequently, blind people are the first to use forms of local integration and exploit the benefits deriving from the experimentation of integration processes ${ }^{2}$. However, still today, in many countries blind people are included as a faveur, as Buton writes in his L'administration des faveurs: l' Etat, les sourds et les

\footnotetext{
${ }^{1}$ See also: Caldin R. (2017). La funzione sociale della ricerca tra possibilità e responsabilità. Nuova Secondaria, 9: 118-124.

${ }^{2}$ For further information, see: Caldin R. (2012). L'inclusione delle persone cieche e ipovedenti nel mondo. In: d'Alonzo L. e Caldin R., a cura di, Questioni, sfide e prospettive della pedagogia speciale. L'impegno della comunità di ricerca. Napoli: Liguori Editore; Caldin R., Zappaterra T. (2016). Pedagogia speciale e deficit visivo. Da Louis Braille ad oggi. In: Crispiani P., a cura di, Storia della Pedagogia speciale. L'origine, lo sviluppo, la differenziazione. Pisa: Edizioni ETS.
} 
aveugles, a book dealing with France between 1780 and 1880, when, according to the author, state policy and the education of the blind and the deaf seemed to proceed hand in hand, even though it was a kind of concession, a merit, a form of charity, without any classification within the logic of law (Buton, 2009, p. 11-26). We wonder if this is really so deplorable or if we can envisage a positive evolution also in the policies of faveur, in other words, we wonder if there are questionable and debatable forms of social inclusion which, in time - thanks to many original factors - undergo an interesting evolution. Perhaps, even some Italian institutions for the blind were established with a logic of faveur - rather than right - but, over the years, have seen positive evolutions leading to the development of facilities for education, rehabilitation and inclusion.

\section{Memory and gratitude}

Between 1974 and 1976 I was a "teacher" at the "L. Configliachi" Institute for the Blind in Padua ${ }^{3}$. I was very young, I had just left high school, and was particularly motivated to work in the field of visual deficit, as I had two classmates at school who were blind or had low vision, and they always amazed me with their extraordinary ability to cope with all the learning obstacles in the classroom, as well as those life reserved for them every day outside. I gained much from both my classmates and those who were to become "my" students at the Institute in Padua, certainly more than I gave back to them: over time this "knowledge" has developed into the clear bond with the extension of competences and development of the professional skills which I acquired later on.

I am certain how lucky I was to meet the young women of the "L. Configliachi" Institute in Padua: my and their impetuosity, unconsciousness and bravery came together and led down unexplored roads, original paths and to unexpected successes. The gift of their extraordinary adolescence/early adulthood deciphered and reinterpreted my own: the shadow line separating youth and adulthood became clear and for me was enriched by unusual elements offered by my students. Conrad (1999) writes: it is the privilege of early youth to live in advance of its days in all the beautiful continuity of hope which knows no pauses and no introspection. One closes behind one the little gate of mere boyishness and enters an enchanted garden. It's very shades glow

\footnotetext{
${ }^{3}$ For further information, see: Tioli E. (2007). L'integrazione scolastica degli alunni con disabilità visiva secondo l'unione italiana dei ciechi e degli ipovedenti: realtà odierna e prospettive. In Integrazione scolastica dei ciechi e degli ipovedenti in Italia e in Europa. Roma: Federazione Nazionale delle Istituzioni Pro-Ciechi, p. 133-143.
} 
with promise. Every turn of the path has its seduction. And it isn't because it is an undiscovered country. One knows well enough that all mankind had streamed that way. It is the charm of universal experience from which one expects an uncommon or personal sensation - a bit of one's own. One goes on recognizing the landmarks of the predecessors, excited, amused, taking the hard luck and the good luck together - the kicks and the halfpence, as the saying is - the picturesque common lot that holds so many possibilities for the deserving or perhaps for the lucky. Yes. One goes on. And the time, too, goes on - till one perceives ahead a shadow-line warning one that the region of early youth, too, must be left behind.

In this work, thanks to the efforts of young blind people and their fight for civil rights, the Conradian shadow line shines through in all its splendour. The whole path to adult choices, filled with responsibility, lies precisely in this effort and in the will to re-interpret, re-establish and re-construct their own situation. For young guests of Italian institutes for the blind, adolescence and early adulthood shine with promise, radiant with a new, chimerical light; the tracks left by their predecessors become springboards for venturing down unexplored avenues, no longer individual but collective; we may glimpse a difficult and complex - shadow line marking the entry into adulthood, marking their liberation from gloomy institutional cages: young blind people become responsible adults, reconstructing their own lives and re-thinking the institutions, in an emancipatory process that from individual becomes collective and of the community. And it is precisely the communities outside of the Italian institutes for the blind that aim to satisfy the dual physiological expectations of adolescents and young people (whether disabled or not): to be welcomed and supported, but also to be taken seriously as persons who are preparing themselves to become adults, and who, to do so, seriously and responsibly want to "change" and improve the society they live in. Indeed, it is in this space that the relationship with adults in the lives of disabled adolescents becomes fundamental, the relationship with these generally tolerant and willing figures who are able to offer more room for manoeuvre for these young people, able to envisage that moratorium as a spatial and temporal transition in which they can experiment experiences, but always within an educational project aiming to ensure that growing up is reprocessed within one's own internal world, understood as the passage to adulthood and ratified by the host community.

As stated by Pietropolli Charmet $(2000 ; 2005)$, adolescence is not understandable by investigating the plot of family events, nor the history of school experiences, but rather considering them the child of the social community in which they love, study, work and grow with all their person, both mind and body: that very body which is cared for, envied, controlled, violated 
or forgotten; sometimes ugly, or missing something, or limited in some or other function, as in the case of blindness or low vision. Adults have the responsibility to raise social awareness, spreading a culture of reduction of handicap which, in relation to disabled adolescents, recognises first and foremost that passionate sharing of the human existence and only thereafter their deficit.

At the time of my experience in youth at the "L. Configliachi" Institute in in Padua, I wanted very much to put my skills to the test - even in problematic situations - and working in the education of young blind and visually impaired students was an irresistible and undeniable challenge for me. My job was to support and assist the girls outside of school hours, helping them with their homework, accompanying them on outings, organising recreational activities in the institution and so on. The first thing I learned from "my" students was that it is possible to laugh about oneself and one's own deficit and that, as "orbi", today produces inestimable results as soon as I apply it; an unexpected discovery, which confused me and forced me to totally review my theories on "poor blind people"; a dangerous surprise, because it hid some resistance to the acceptance of the deficit; an extraordinary discovery, because it showed me the normality of adolescence, with all the humour, discouragements and excesses that it usually holds. I found myself having to deal with adolescents who were very similar to me: there was only a minimal age difference, cancelled out and even balanced in their favour, as they were much "older" than me in age; my students stood out for their feelings, desires, emotions that I myself felt (and at times I lost myself in), by managing to laugh at their own condition (and, in doing so, to lighten the burden) and teaching me new approaches to problematic situations, offering me new lenses with which to read the complexity of the reality we live in. I never forgot how - despite it all - the ability of those institutionalised adolescents to "be a group" brought excellent results; spending so much time together in the same place, sharing their problems and dreams, seemed to make them bold and insightful, ironic and brave, courageous and resolute. Only a few of the young students, on rare occasions, felt sorry for themselves, but were instantly called to order by the strength and courage of the other girls. For a long time, I wondered where that strength, that irony, that detachment came from, which on one hand helped them to overcome their deficit, and on the other, however, it distanced, hid, denied. And yet, this was exactly the sense of my educating: capturing that lightness, at times

\footnotetext{
${ }^{4}$ Despite the word's clearly Latin origin - orbati, i.e. deprived of something (in this specific case, sight) - in this context, the word is used with reference to Veneto dialect, indicating people with clear visual deficits.
} 
exaggerated, taking and reducing it, in a condition that maintained the detached and delicate character of disability yet at the same time integrating it with more realistic prospects, covered with responsibility and a genuine sense of challenge.

The lack of imagination and planning by parents and adults generally in the life project of disabled minors risks converting a limit (blindness or low vision), which can be overcome with appropriate aids, into an insurmountable obstacle, worsening the situation with handicapping elements (overprotection, lack of experimentation and acquisition of autonomy, untimely practice of guidance) which are not attributable to the deficit itself and which must be identified and isolated through education. Education in fact has the responsibility of limiting and mitigating elements which worsen the deficit, circumscribing it, depriving it of handicapping components: visual disability is a deficit at great risk of being soaked in deteriorating, aggravating elements and risks being moulded to both the direct effects as well as the side effects. This is why the social context and personal resources are privileged areas of intervention, if we wish to avoid handicapping the deficit even further, and this is where the young blind girls focus the enthusiasm of their youth, their passionate need for education and their rigorous civil and political commitment.

In my work at the "L. Configliachi" Institute in Padua, I felt like a big sister who, day by day, learned from other sisters and learned to return what I learned in more professional, sophisticated forms and methods, free of all polluting, prejudicial and distorting elements. A normal adolescence - my own - was defined and integrated by suffered, joyful, acquired and lost, fertile and limited adolescences, complete and partial at the same time which showed me, for the first time, and with unambiguous clarity, the tangibility of educational situations without antimony and rich in oppositions, chiaroscuros, positive ambiguities. I began to doubt that salvific inspiration which had driven me to choose that work; I began to be suspicious of those charitable certainties carved in stone which in previous years I had built in relation to disabled and blind people. All that I learned and received in my experience with these students still marks my time and professional career today: the experience of reciprocity in educating transformed, renewed and developed my approach to disability. The debt I have to "my" students at the Institute in Padua is still immense and priceless.

In the meeting between my own adolescence and that of the young students in my charge, I developed a strong consciousness of the situation they lived in and, with determination and conviction, I took part in the protests against the administration in the "L. Configliachi" Institute in Padua between 1975 and 1976. These disputes led to the greater opening of the Institute and its students to the local community, and also better treatment of the teaching staff. This also 
occurred through a new form of contract and a new alliance between the adults overseeing the educational area. The construction of new alliances can be the instrument used by the adult world to think what adolescents cannot think and communicate to themselves and the world in the form of action (at times inadequate, self-harming, damaging and irreversible actions), as the action of adolescents should already be offered a large distiller, prepared by adults together, able to restore meaning to meaningless actions, thought to the unthinkable, words to silent affections and eyes to see, for those who do not have them (Pietropolli Charmet, 2000).

Therefore, we must govern the social birth of all adolescents, threatened by hazards that we must not underestimate, amplified by the consumer society we live in: spreading not just protective but also emancipatory ideals, as an antidote to the failure of the evolutionary tasks of this stage of development, seems an indispensable indication and an encouraging start, even in situations of disability. All too frequently, educational methods are still highly calibrated towards protection and the satisfaction of needs (while positive, this is partial), but are much less calibrated to personal commitment, achievement and effort, and the drive to grow which also imply the experience of frustration, limit and renunciation: fundamental methods for the mental, relational, affective, emotional and physical health of young disabled persons. Rights (to have a family, belong to a community, be loved, etc.) must be combined with duties (towards oneself and others, etc.), through educational experiences offering significant models and testimonials.

The battles in Padua and other institutes for the blind in Italy seem to pursue a pedagogical idea of utopia and change as a regulatory idea: usually, utopia calls on pedagogy to give meaning to education not closed in repetition and reproduction and, therefore, in the conservation of what already exists, but rather seeking it in the very origins of the educational experience, escaping the flattery of the present and the immediately feasible. From this viewpoint, utopia is not assigned elusive, consolatory functions but rather those of a powerful, driving device which dilates and amplifies the range of paths to follow, as happened in the various Institutes in Italy, in the years before deinstitutionalisation, thanks to the explosive driving force of the young blind people. Like the possible of tomorrow, utopia represents and maintains its driving, guiding force and not that towards an exclusive, perhaps never reached destination (Bertolini, 1999) ${ }^{5}$.

${ }^{5}$ See also: Contini M. (1999). Possibilità, progettualità, impegno. Studium Educationis, 2 : 258-263; Orlando D. (1997). Metodologia della ricerca pedagogica. Brescia: La Scuola; Xodo C. (2007). Introduzione alla filosofia dell'educazione. Padova: Cleup; Caldin R. (2007). Introduzione alla pedagogia speciale. Padova: Cleup. 
If there is anything to regret in this experience and these memories, this concerns the currently evident lack of utopia and lack of pedagogic design that lead every action and every project to be confined to a single temporal dimension, the present, denying any possible evolution or improvement, flattening out and uniformising heuristic paths, hindering underlying potential, moving towards a lack of educational commitment and responsibility, forcing the young generations into negligence, reducing educational decisions and choices to superficiality, exteriority and transience, dragging down even those who should be oriented and guided by adults into a brutal spiral of a narcissistic society (Bertolini, 1998).

\section{The responsibility of change}

The intentions of the stakeholders - our young blind protagonists - fully meet an ethical imperative indicated by Von Foerster, who sees the consequent educational choices as a source of new opportunities (the modern capabilities?) for themselves and others: "do, ut possis dare, i.e. always acting in a manner that increases the total number of possible choices" (Von Foerster, 1987: p. 233). The scholar includes this indication in a broader approach to the assistance relationship and the "social" intervention: he indicates how those who help can seek to spot in the other an identity which goes beyond that monotonous and impersonal nature of the needy and the disadvantaged (disabled people, prisoners, refugees, etc.). According to the author, "seeing is believing", we have to patiently trust and accept educational challenges, because otherwise we risk seeing only what we already know, what is familiar, what we expect or presume, basing our actions on prejudice rather than on intentions, promoting interpersonal relations which highlight the many identities of the other, considering, for example, not only the personality of the person acquiring a disability - after an accident or trauma - but also that which he or she demonstrated prior to the disability. Those committed to change not only call into question the possibility of change but also the responsibility, which also holds within it that fear which leads us to perform an action: "Do not allow fear to prevent action, but rather feeling responsible in advance for the unknown, faced with the final uncertainty of hope, precisely constitutes a condition of the responsibility of action: that which we call the "courage of responsibility" (Jonas, 1993): responsibility is indeed linked to the decision and the action that follows. To do this, thought must be subjected to the obligation of doing (acting consistently with the intention) to obtain significant changes. Chionna wrote that, "the most advanced forms of social responsibility lead to political action, beyond any individualism and fragmentation, within history, 
in the construction of the community and in contributing to the promotion of the 'common good' and 'social peace', in the exercise of potentially widespread responsible action" (1999, p. 276-281) and it is precisely in this cultural and existential framework that the social and political commitment of young blind people shines through.

According to the indications of Jonas, heuristic experience produces responsibility, because the knowledge linked to experience is no longer a limited horizon but leads to very broad dimensions and has repercussions far away in time and space. Responsibility, which according to Jonas is a common trait of both parents towards their newborn children and the head of state towards his citizens, is taking care of others - also in the meaning of generativity so dear to E. H. Erikson $(1950 ; 1958 ; 1968)$, whether they be a companion, pupil, sibling, child, or our fellow beings. Therefore, adults must be urged to extend their generational attention to all children, not just their own, extending family responsibility to make it social: this means a collective responsibility towards the young generations, which no longer separates private self-realisation from generational responsibility (Scabini, 1995).

The young blind people taking part in the many civil and political battles grow up, taking care not only of themselves but many others - even those they do not know - who live in a similar condition. The beauty of their action derives from the existential greatness of these young people who develop and mature, helping their own community and even more distant communities to develop and mature, in a dimension of reciprocity and co-evolution that represents the stylistic signature of generative and responsible adults. It is the response people are called on to give by the responsibility of being in the world: it indicates the constant human striving to overcome unilateral and alienating existential forms, not structured into solipsistic forms: realise yourself by realising others is the imperative that expresses this commitment and the striving to pursue it, knowing that it is a path that will never ultimately be concluded. And despite the impossibility, due to the dimension of heuristic commitment, of envisaging an epilogue to the journey, this path may be revealed to be winning because it promotes the existential experimentation we are all entitled to.

The commitment indicates a right/duty of each of us to reconcile to totally opposing, yet interdependent needs which must be met together: the rights/duties of others and personal rights/duties. In this way, we may also contain the reassuring flattery of beaten roads, instead preferring original and unknown itineraries which are always determined by risks, hazards and uncertainties, but also by the huge resources and infinite wealth that the educational adventure of research and discovery of unknown paths can offer (Heidegger, 1972). 
This is also what the young blind people I knew did, these daring protagonists of civil and political battles which changed the educational institutions in Italy, the cultural approach and practices of visual deficits and disability generally. We are grateful to them and their passionate, intense, youthful commitment, and we are in their debt.

\section{References}

Bertolini P. (1998). L'esistere pedagogico. Firenze: La Nuova Italia.

Bertolini P. (1999). Intenzionalità, rischio, irreversibilità, utopia. Studium Educationis, 2: $257-261$.

Buton F. (2009). L'administration des faveurs: l'Etat, les sourds et les aveugles (17891885). Rennes: Presses Universitaires de Rennes.

Caldin R. (2007). Introduzione alla pedagogia speciale. Padova: Cleup.

Caldin R. (2012). L'inclusione delle persone cieche e ipovedenti nel mondo. In: d'Alonzo L. e Caldin R., a cura di, Questioni, sfide e prospettive della pedagogia speciale. L'impegno della comunità di ricerca. Napoli: Liguori Editore.

Caldin R., Zappaterra, T. (2016). Pedagogia speciale e deficit visivo. Da Louis Braille ad oggi. In: Crispiani P., a cura di, Storia della Pedagogia speciale. L'origine, lo sviluppo, la differenziazione. Pisa: Edizioni ETS.

Caldin R. (2017). La funzione sociale della ricerca tra possibilità e responsabilità. Nuova Secondaria, 9: 118-124.

Canevaro A. (1999). Pedagogia speciale: la riduzione dell'handicap. Milano: Mondadori Editori.

Canevaro A. (2013). Pedagogia Speciale: Lessico. Italian Journal of Special Education for Inclusion, 1:182-185.

Chionna A. (1999). Responsabilità. Studium Educationis, 2: 276-281.

Conrad J. (1999). La linea d'ombra: una confessione. Milano: Mondadori Editori.

Contini M. (1999). Possibilità, progettualità, impegno. Studium Educationis, 2: 258263.

Erikson E. H. (1950). Childhood and Society. New York: W.W. Norton \& Co. Inc.

Erikson E. H. (1958). Young Man Luther. A study in Psychoanalysis and History. New York: W.W. Norton \& Co. Inc.

Erikson E. H. (1968). Identity Youth and Crisis. New York: W.W. Norton \& Co. Inc.

Ghedin E. (2010). Ben-essere disabili: un approccio positivo all'inclusione. Napoli: Liguori Editore.

Goffman E. (1970). Stigma: l'identità negata. Bari: Laterza.

Heidegger M. (1976). Essere e tempo. Milano: Longanesi.

Jonas H. (1993). Il principio responsabilità: un'etica per la civiltà tecnologica. Torino: Einaudi.

Musil R. (1957). L'uomo senza qualità. Torino: Einaudi.

Orlando D. (1997). Metodologia della ricerca pedagogica. Brescia: La Scuola. 
Pietropolli Charmet G. (2000). I nuovi adolescenti: padri e madri di fronte a una sfida. Milano: Raffaello Cortina.

Pietropolli Charmet G. (2005). Adolescenza: istruzioni per l'uso. Milano: Fabbri Editori.

Scabini E. (1995). Psicologia sociale della famiglia. Torino: Bollati Boringhieri.

Sen A. K. (1999). Development as freedom. New York: Knopf.

Tioli E. (2007). L'integrazione scolastica degli alunni con disabilità visiva secondo l'unione italiana dei ciechi e degli ipovedenti: realtà odierna e prospettive. In Integrazione scolastica dei ciechi e degli ipovedenti in Italia e in Europa. Roma: Federazione Nazionale delle Istituzioni Pro-Ciechi.

Von Foerster H. (1987). Sistemi che osservano. Roma: Astrolabio.

Xodo C. (2007). Introduzione alla filosofia dell'educazione. Padova: Cleup. 